2011

\title{
International Civil Service Ethics, Professionalism and the Rule of Law
}

Lorne Sossin

Osgoode Hall Law School of York University, lsossin@osgoode.yorku.ca

Vasuda Sinha

Follow this and additional works at: http://digitalcommons.osgoode.yorku.ca/all_papers

\section{Repository Citation}

Sossin, Lorne and Sinha, Vasuda, "International Civil Service Ethics, Professionalism and the Rule of Law" (2011). All Papers. Paper 50.

http://digitalcommons.osgoode.yorku.ca/all_papers/50 


\title{
International Civil Service Ethics, Professionalism and the Rule of Law Lorne Sossin \& Vasuda Sinha \\ Faculty of Law \\ University of Toronto
}

\author{
This paper was prepared for the Workshop \\ "Ethical Supports For Strengthening The International Rule of Law" \\ Institute for Ethics, Governance and Law \\ October 19, 2009
}

\section{Not for Citation without Permission}

While the idea of public service independence and its relationship to the rule of law has received significant recognition in the Canadian context, ${ }^{1}$ it raises the question of whether an analogous set of ethical norms operate at the international level, in settings such as the United Nations and its agencies, the European Commission and other settings of multilateral governance. Is an independent, global or multilateral public service a necessary precondition for an international rule of law? By what mechanisms does the operation of bureaucracy in multilateral governance strengthen (or erode) the international rule of law?

In this brief paper, we examine the ethics and professionalism of the international public service - the individuals who collectively comprise the international organizations ("IO"s) that exercise authority through the auspices of entities recognized by international $\mathrm{law}^{2}$ - and reflect on the potential of the operation of such ethics and professionalism to define and enhance the concept of the international rule of law.

The rule of law is not self-executing. It depends on decision-makers understanding and respecting the limits of their authority and oversight mechanisms with the capacity and commitment to enforce the rule of law when necessary. While enforcement takes on a different character in international settings, the role of civil servants both in reflecting and instilling a rule of law culture is no less, and perhaps even more, important.

As in any public organization, the most significant bulwark against infringements of the rule of law is the rank and file members of the organization itself. Jose Alvarez describes the emergent role of international civil servants in these terms:

\footnotetext{
${ }^{1}$ L. Sossin, "Speaking Truth to Power? The Search for Bureaucratic Independence" (2005) 55 University of Toronto Law Journal 1-60; and a subsequent version of this research commissioned by the Inquiry into the Sponsorship Affair (the "Gomery Inquiry") was published by the Gomery Inquiry as L. Sossin, "Defining Boundaries: The Constitutional Argument for Bureaucratic Independence and Its Implication for the Accountability of the Public Service" (February 2006).

${ }^{2}$ While there are many IOs which might fit these criteria, for the purposes of this study, I will focus on the United Nations and its agencies.
} 
Of course, the move to IOs has created a new category of actor on the world scene: international civil servants. These new non-state actors owe their power to their titles and function, whether we call them "secretary general," "U.N. expert," or "special rapporteur," or "international judge." Their capacity to act and their legitimacy as actors stem from the fact that they are agents of neutrality or of centralization. They are treated as legitimate insofar as they are not the mere agents of particular states but the representative of all of them, and perhaps of the global public interest. These actors are supposed to be autonomous from the nations they come from. ${ }^{3}$

The notion of an international civil servant's autonomy from her country of origin is important, as it suggests that her loyalty is owed not to that country, but to a different master. At a high level these questions about loyalty raise issues that are analogous to domestic tensions that have been examined in the context of liberal democracies, between a civil servant's political neutrality and the danger of civil servants advancing the partisan aims of a particular political party. In global and multilateral settings, the tension lies not between public servants and the partisanship of elected politicians but rather between public servants and the politics of national governments. Just as public servants also rely on elected politicians in liberal democracies for their legitimacy, so international public servants rely on national governments for their legitimacy.

In this study, taking the United Nations as the example, we explore how, as a matter of employment, international civil servants at the United Nations must follow direction from their supervisors, in a chain of command, with the Secretary General as the Chief Administrative Officer. But U.N. officials, we suggest, must also be seen to owe a broader (and, when necessary, overriding) duty of loyalty to a set of foundational principles rooted in the global public interest, and the foremost such principle, we argue, is the international rule of law.

Our analysis of this claim proceeds in three parts. First, we attempt to situate the international rule of law within the foundational principles of the United Nations, and to ascribe to it some tangible features that impose obligations on those engaged in decision-making at the UN. Second, we explore the implications of the independence of the international civil service, and what mechanisms exist to resolve disputes which might arise around their potentially competing duties. Third, by way of conclusion, we suggest several areas of uncertainty which will need to be resolved if the international civil service is to function as guardian of the international rule of law.

\footnotetext{
${ }^{3}$ Jose E. Alvarez, "Distinguished Speaker Series: Governing the World: International Organizations as Lawmakers” (2008) 31 Suffolk Transnat'1 L. Rev. 591 at 597-98.
} 


\section{Part One: The International Rule of Law}

While ideas on the scope and nature of the rule of law will (and should) differ, the concept may be seen, at a minimum, to capture four central ideas. The first idea is that no one is above the law. Those who hold power and influence, in other words, must abide by the same rules as those who do not. The second and related idea is that all power has limits. Discretion is never unbounded and authority always comes with enforceable constraints. No one, in other words, can be empowered to act arbitrarily in relation to the rights and interests of others. Third, the rule of law includes a commitment to fairness and equality in the exercise of authority. Fourth, the rule of law demands accountability and remedy where demonstrable infringements to fairness and equality have occurred.

The Report of the Secretary General on "The Rule of Law and Transitional Justice in Conflict and Post-Conflict Society" elaborates a similar understanding of the rule of law within the United Nations context:

For the United Nations, the rule of law refers to a principle of governance in which all persons, institutions and entities, public and private, including the State itself, are accountable to laws that are publicly promulgated, equally enforced and independently adjudicated, and which are consistent with international human rights norms and standards. It requires, as well, measures to ensure adherence to the principles of supremacy of law, equality before the law, accountability to the law, fairness in the application of the law, separation of powers, participation in decision-making, legal certainty, avoidance of arbitrariness and procedural and legal transparency. ${ }^{4}$

Protecting and advancing the rule of law in domestic and international settings is at the heart of the United Nations' mission. As the Secretary General's Report suggests, instilling respect for the rule of law is fundamental to resolving conflicts and to the transition from war to peace. It is also central to the promotion of human rights, social cohesion and economic development.

The General Assembly considered the rule of law as an agenda item several times in the 1990s, with renewed interest since 2006 and has adopted resolutions at its last three sessions. ${ }^{5}$ The Security Council has held a number of debates on the rule of law, ${ }^{6}$ and adopted resolutions emphasizing the importance of these issues in the context of women,

${ }^{4}$ S/2004/616. See also Secretary General's report "Uniting Our Strengths: Enhancing United Nations Support for the Rule of Law" (A/61/636); and "Strengthening and Coordinating United Nations Rule of Law Activities" (A/63/226).

${ }^{5} \mathrm{~A} / \mathrm{RES} / 61 / 39, \mathrm{~A} / \mathrm{RES} / 62 / 70, \mathrm{~A} / \mathrm{RES} / 63 / 128$.

${ }^{6}$ See S/PRST/2003/15, S/PRST/2004/2, S/PRST/2004/32, S/PRST/2005/30, S/PRST/2006/28. 
peace and security, children in armed conflict, and the protection of civilians in armed conflict. According to the U.N.'s "Rule of Law" unit, over 40 U.N. entities are engaged in rule of law issues and the rule of law operations and programming takes place in over 110 countries in all regions of the globe, with the largest presence in Africa. Five or more entities are currently working simultaneously on the rule of law in at least 24 countries, the majority of which are in conflict and post-conflict situations. ${ }^{7}$

The principle of the rule of law embedded in the Charter of the United Nations encompasses elements relevant to the conduct of State to State relations. The main United Nations organs, including the General Assembly and the Security Council, have essential roles in this regard, which are derived from and require action in accordance with the provisions of the Charter. However, it falls to the international civil service (and international judicial bodies such as the International Court of Justice and ad hoc criminal tribunals) to transform commitment to the rule of law into tangible action. ${ }^{8}$ It is to a discussion of the ethics of the international civil service, including its commitment to the rule of law, that we now turn.

\section{Part Two: Rules and Regulations Governing the International Civil Service}

The Charter contemplates that a civil service is needed to bring the other commitments enshrined in its provisions to life. Article 97 of the Charter, for example, provides that the U.N. Secretariat, "shall comprise a Secretary-General and such staff as the Organization may require. The Secretary-General shall be appointed by the General Assembly upon the recommendation of the Security Council. He shall be the chief administrative officer of the Organization."

The Articles in the Charter which speak to the independence of the Secretary-General and her or his staff provide:

${ }^{7}$ The Rule of Law activities of the U.N. itself requires a substantial civil service commitment. Responsibility for the overall coordination of rule of law work rests with the Rule of Law Coordination and Resource Group, chaired by the Deputy SecretaryGeneral and supported by the Rule of Law Unit. The membership of the Group consists of the Department of Political Affairs (DPA), the Department of Peacekeeping Operations (DPKO), Office of the High Commissioner for Human Rights (OHCHR), the Office of Legal Affairs (OLA), United Nations Development Programme (UNDP), The United Nations Children's Fund (UNICEF), UNHCR, the United Nations Development Fund for Women (UNIFEM) and the United Nations Office on Drugs and Crime (UNODC).

${ }^{8}$ For discussion of the commitment of these bodies to developing an international rule of law, see Chandra Lekha Sririam, "International rule of law? A comparative analysis of domestic and international courts and tribunals" prepared for the "Ethical Supports For Strengthening The International Rule of Law" Conference of the Institute for Ethics, Governance and Law, October 19, 2009. 
Article 100

1. In the performance of their duties, the Secretary-General and the staff shall not seek or receive instructions from any Government or from any other authority external to the Organization. They shall refrain from any action which might reflect on their position as international officials responsible only to the Organization.

2. Each Member of the United Nations undertakes to respect the exclusively international character of the responsibilities of the Secretary-General and the staff and not to seek to influence them in the discharge of their responsibilities.

Article 101

1. The staff shall be appointed by the Secretary-General under regulations established by the General Assembly.

2. Appropriate staffs shall be permanently assigned to the Economic and Social Council, the Trusteeship Council, and, as required, to other organs of the United Nations. These staffs shall form a part of the Secretariat.

3. The paramount consideration in the employment of the staff and in the determination of the conditions of service shall be the necessity of securing the highest standards of efficiency, competence and integrity. Due regard shall be paid to the importance of recruiting the staff on as wide a geographical basis as possible.

Article 105

1. The Organization shall enjoy in the territory of each of its Members such privileges and immunities as are necessary for the fulfilment of its purposes. 2. Representatives of the Members of the United Nations and officials of the Organization shall similarly enjoy such privileges and immunities as are necessary for the independent exercise of their functions in connection with the Organization.

These provisions lay the groundwork for and provide legitimacy to an independent civil service within the U.N. The employees of IOs such as the United Nations traditionally have been considered to be international civil servants, that is, public servants to the international community, with an obligation to respect and promote the values of international law. ${ }^{9}$

The seemingly clear, traditional mandate of the international civil service notwithstanding, the boundaries of international civil service ethics are not easily defined.

\footnotetext{
${ }^{9}$ See see Aamir Ali, “The International Civil Service: The Idea and the Reality, in International Administration" in Law and Management Practices in International Organisations (Chris de Cooker ed., 1990). See also Jacque Lemoine, The International Civil Servant: An Endangered Species 15-27 (1995).
} 
Civil servants at the U.N. owe a duty of loyalty to the U.N. and to follow the direction of those delegated authority within the organization. The Charter also speaks to the duty of U.N. civil servants to adhere to ideals of efficiency, competence and integrity and not to openly disparage their employer. Beyond these regular duties of an employee to his employer, the special context of the U.N. is taken also to impose broader duties on international civil servants to uphold fundamental U.N. principles (which include, of course, respect for the rule of law, as indicated above).

The primary source for civil servant ethics at the U.N. are the "Staff Regulations," 10 the provisions of which include:

\section{General rights and obligations Regulation 1.2 Core values}

(a) Staff members shall uphold and respect the principles set out in the Charter, including faith in fundamental human rights, in the dignity and worth of the human person and in the equal rights of men and women. Consequently, staff members shall exhibit respect for all cultures; they shall not discriminate against any individual or group of individuals or otherwise abuse the power and authority vested in them;...

(c) Staff members are subject to the authority of the Secretary-General and to assignment by him or her to any of the activities or offices of the United Nations. In exercising this authority the Secretary-General shall seek to ensure, having regard to the circumstances, that all necessary safety and security arrangements are made for staff carrying out the responsibilities entrusted to them;

(d) In the performance of their duties staff members shall neither seek nor accept instructions from any Government or from any other source external to the organization;

(e) By accepting appointment, staff members pledge themselves to discharge their functions and regulate their conduct with the interests of the Organization only in view. Loyalty to the aims, principles and purposes of the United Nations,

${ }^{10}$ According to the Staff Regulations, they are intended to "embody the fundamental conditions of service and the basic rights, duties and obligations of the United Nations Secretariat. They represent the broad principles of human resources policy for the staffing and administration of the Secretariat. For the purposes of these Regulations, the expressions "United Nations Secretariat", "staff members" or "staff" shall refer to all the staff members of the Secretariat, within the meaning of Article 97 of the Charter of the United Nations, whose employment and contractual relationship are defined by a letter of appointment subject to regulations promulgated by the General Assembly pursuant to Article 101, paragraph 1, of the Charter. The Secretary-General, as the chief administrative officer, shall provide and enforce such staff rules consistent with these principles as he or she considers necessary." 
as set forth in its Charter, is a fundamental obligation of all staff members by virtue of their status as international civil servants;

(f) While staff members' personal views and convictions, including their political and religious convictions, remain inviolable, staff members shall ensure that those views and convictions do not adversely affect their official duties or the interests of the United Nations. They shall conduct themselves at all times in a manner befitting their status as international civil servants and shall not engage in any activity that is incompatible with the proper discharge of their duties with the United Nations. They shall avoid any action and, in particular, any kind of public pronouncement that may adversely reflect on their status, or on the integrity, independence and impartiality that are required by that status;

(g) Staff members shall not use their office or knowledge gained from their official functions for private gain, financial or otherwise, or for the private gain of any third party, including family, friends and those they favour. Nor shall staff members use their office for personal reasons to prejudice the positions of those they do not favour

(h) Staff members may exercise the right to vote but shall ensure that their participation in any political activity is consistent with, and does not reflect adversely upon, the independence and impartiality required by their status as international civil servants;

(i) Staff members shall exercise the utmost discretion with regard to all matters of official business. They shall not communicate to any Government, entity, person or any other source any information known to them by reason of their official position that they know or ought to have known has not been made public, except as appropriate in the normal course of their duties or by authorization of the Secretary-General. These obligations do not cease upon separation from service;... ${ }^{11}$ [Emphasis added].

While these provisions speak to a variety of ethical priorities, the highlighted passages above point to the importance of the twin ethical pillars of "internationalism" and "independence." The principle of internationalism is somewhat self-explanatory: it requires international civil servants to conduct themselves not in the interests of particular states but in accordance with the multilateral interests of the U.N. The meaning and implication of the principle of independence requires more careful elaboration. Most importantly, it raises the questions of from whom and what must international civil servants be independent: National governments? The U.N. General Assembly? Other international actors, such as multinational corporations and NGOs? To some extent, the independence of the international civil service must address each of these concerns. Independence requires objective guarantees and protections. In other words, if civil servants are vulnerable to being terminated or sanctioned for decisions which certain states dislike, independence may be by the mere possibility of such a

\footnotetext{
${ }^{11}$ ST/SGB/2011/1. In addition to the Staff Regulations, a series of Staff Rules are also set out for U.N. civil servants, which cover a range of topics from the duty of loyalty to the Secretary-General, to conflict of interest and improper influence provisions, to discrimination and harassment, and rules prohibiting acceptance of gifts.
} 
form of reprimand, without the need for any realization on the threat thereof. Independence is as much a matter of perception as one of reality.

A full discussion of civil service independence as a legal guarantee is beyond the scope of this study. ${ }^{12}$ Generally, independence has been developed with the rule of law and fairness in the adjudicative process in mind. It is well established that international human rights law entitles each individual to a fair and public hearing by an independent and impartial tribunal in the determination of his or her rights and obligations. This right is expressly guaranteed in several international declarations and conventions, including the Universal Declaration of Human Rights, ${ }^{13}$ the International Covenant on Civil and Political Rights, the European Convention for the Protection of Human Rights and Fundamental Freedoms and the American Convention on Human Rights. $^{14}$

With respect to adjudicative independence, it has been observed, based on a wideranging review of state constitutions, legislation and supporting state practice, that "the general practice of providing independent and impartial justice is accepted by states as a matter of law" and is thus a customary norm of international law. ${ }^{15}$ This principle is easier to invoke, however, than to implement. If the justice to be found at the United Nations is independent of the General Assembly and its member states, to whom are decision-makers and adjudicators accountable? Clearly, the international public service must rely for its legitimacy on the U.N.'s legislative arm. It must discharge duties which are set out in the resolutions and legislative instruments of the U.N., and must answer to the Secretary General as set out above in the Staff Rules. In this sense, independence and accountability must be seen as mutually reinforcing public service norms if an international rule of law is to be meaningfully advanced.

The international civil service does not exist in a vacuum. Rather, civil servants work for public bodies with particular mandates and powers. IOs are initiated by states attempting to serve public purposes. Starting in 1865, with the establishment of the International Telegraph Union, more than 80 IOs are now recognized. These IOs

12 For discussion of independence as a legal guarantee both in national and international contexts, see Gerald Heckman and Lorne Sossin, "How Canadian Administrative Law Protections Measure up to International Human Rights Standards" (2005) 50 McGill Law Journal 193-264.

${ }^{13}$ GA Res. 217(III) UN GAOR, 3d Sess., Supp. No. 13, UN Doc. A/810 (1948) 71, Art. 10.

1422 November 1969, 65 A.J.I.L. 679, Art. 8.

${ }^{15}$ Commission on Human Rights, Sub-Commission on Prevention of Discrimination and Protection of Minorities, Independence and Impartiality of the Judiciary, Jurors and Assessors and the Independence of Lawyers - report by the Special Rapporteur Param Cumaraswamy, UN Doc. E/CN.4/1995/39 (1995) at para. 35. 
typically enjoy immunity from the jurisdiction of member states' courts so as to preserve their independence and international character.

This commitment to independence has particular relevance for the members of international tribunals, but more broadly speaks to the importance of fairness and equity in the application of public authority. Independence is an important norm for an international civil service precisely because the decisions made by its members affect people (often the most vulnerable people), in areas ranging from the allocation of economic resources, humanitarian assistance, regulatory oversight, and military intervention.

\section{The ILO Administrative Tribunal}

While the immunity of IOs vis-à-vis national courts is critical to their independent operation, a significant ancillary effect thereof was to preclude their employees from having recourse to any national employment laws. Historically, it fell on administrative tribunals generally, and the International Labor Organization (ILO) Administrative Tribunal (the "ILO Tribunal") specifically, to elaborate and enforce the independence of members of the international civil service. The Tribunal was established in 1946 as the successor to the League of Nations Tribunal (1927 to 1946). The seven judges of the ILO Tribunal are appointed for three year renewable terms by the ILO Conference, the highest organ of the ILO. The judges are of different nationalities and typically have been well-regarded judges in their countries. Usually, they sit in panels of three, but larger panels are permitted for exceptional cases. Another tribunal with a similar jurisdiction is the United Nations Administrative Tribunal (UNAT), established in New York in 1949 to receive complaints from the UN and the UN specialized agencies. The World Bank and the IMF also have their own administrative tribunals which deal with, among other disputes, complaints from staff at those organizations.

The ILO Tribunal (and, to a lesser extent, other tribunals) have performed a critical rule of law function in ensuring oversight in relation to the professionalism of the international civil service.

For example, in Bustani v. Organisation for the Prohibition of Chemical Weapons Judgment, ${ }^{16}$ the ILO Tribunal found that Jose Bustani ("Bustani") was unlawfully dismissed from the post of director-general of the Organisation for the Prohibition of Chemical Weapons (OPCW) ${ }^{17}$ in April 2002 as a result of political interference. In reaching this conclusion, the Tribunal affirmed the importance of the independence of

\footnotetext{
${ }^{16}$ No. 2232.: At <http://www.ilo.org/public/english/tribunal/>. Administrative Tribunal of the International Labour Organization, July 16, 2003.

${ }^{17}$ The OPCW was established in 1997 under the 1993 Convention on the Prohibition of the Development, Production, Stockpiling and Use of Chemical Weapons and on Their Destruction (CWC).
} 
IOs and their secretariats, and condemned political interference by member states in their workings.

Bustani was appointed as the first director-general of the OPCW in May 1997, with a four-year term. During his time at the OPCW, he and his inspectors oversaw the destruction of two million chemical weapons and two-thirds of the world's chemical weapons facilities. A year before the expiry of his term, the Conference unanimously extended it for another four years.

In March 2002, in the lead up to the American invasion of Iraq, ${ }^{18}$ the United States submitted a no-confidence motion at the twenty-eighth session of the Council. Alleging mismanagement, demoralization of the Technical Secretariat, and ill-considered initiatives, the motion called for Bustani to resign. The motion failed, and the United States called a special, April 2002 session of the Conference, where the motion to dismiss narrowly carried.

In July 2002, Bustani commenced proceedings before the ILO Tribunal, claiming unlawful termination of his employment contract. For the first time in its history, the Tribunal reviewed the decision of an international organization to remove its head. ${ }^{19}$ The Tribunal held, however, that a decision terminating the appointment of an international civil servant prior to the expiry of his/her term of office is an administrative decision, even if it is based on political considerations. The fact that the decision is a political one made by the U.N.'s highest decision-making body cannot exempt it from the necessary review applying to all individual decisions which are alleged to be in breach of the terms of an appointment or contract, or of statutory provisions. Politics, in other words, does not come before law.

The Tribunal condemned the political interference exerted by states, and particularly the United States, in the operation of the OPCW. The Tribunal stated that "the independence of international civil servants is an essential guarantee, not only for the civil servants themselves, but also for the proper functioning of international organisations." ${ }^{20}$ It argued that appointments for fixed terms are the means of ensuring that the heads of international organizations remain independent. If the Conference, for example, were given unfettered discretion to terminate Bustani's appointment, he and others would become "vulnerable to pressures and to political change." 21

\footnotetext{
${ }^{18}$ Bustani and Hans Blix both advocated a non-violent approach to claims about Iraq's possession of weapons of mass destruction.
}

${ }^{19}$ The OPCW challenged the jurisdiction of the Tribunal to hear the case, alleging that the director-general position was a political appointee and not a civil servant able to challenge termination. The Tribunal ruled that Bustani was an "official" and therefore able to seek a remedy before the Tribunal.

${ }^{20}$ Bustani, at para. 16.

${ }^{21}$ Ibid 
The Tribunal held that only in exceptional cases involving grave misconduct and the like, should heads of international organizations be removed, but even then the decision to terminate such an appointment must be "taken in full compliance with the principle of due process, following a procedure enabling the individual concerned to defend his or her case effectively before an independent and impartial body." ${ }^{22}$ Bustani received 50,000 Euros in moral damages and "the amount he would have received in salaries and emoluments" between the date of his dismissal and the end of his second four-year term. ${ }^{23}$

In a comment on this case, ${ }^{24}$ David Caron and Ana Stanic observe that the ramifications of the case extend beyond questions regarding the independence of the OPCW, and go to the very foundation of the international legal and political framework. They note that the fundamental premises of our present international framework are the equality of states, the multilateral nature of international organizations, and the functional autonomy of such organizations. The Bustani case, in their view, highlights the urgent need to develop new procedures and mechanisms to ensure that international organizations and their staffs remain immune from such interference. Otherwise, the multilateral nature of the present international order will be reduced to being "unilateralism in a multilateral disguise." 25 Thus, cases such as Bustani are cautionary tales that cut both ways. On the one hand, the case demonstrates that there is a mechanism for accountability once the independence of the civil service has been compromised. On the other hand, this form of accountability did nothing to undo the decision, and is unlikely on its own to deter such occurrences in the future.

Other cases have led to more significant institutional changes. For example, the ILO Tribunal had earlier confronted the issue of citizens of Eastern European states in the international civil service during the Cold War. The general practice followed by the United Nations in recruiting national civil servants during the early 1980 s was to request that the government concerned release them for U.N. service, whether on secondment or otherwise. Sometimes a candidate would resign from the national civil service, while other times, a secondment was arranged. A seconded civil servant, whose government was opposed to his or her reappointment by the Organization, could resign from the national civil service and be appointed as an international civil servant. This option was not available for staff members from Communist states.

The 1980 decision by the ILO Tribunal in re Rosescu, explored the issue of the independence of the international civil service from the perspective of proper and improper loyalties of civil servants. Rosescu, the complainant in the case and a Romanian citizen, joined the staff of the International Atomic Energy Agency (IAEA) in 1975 as a

${ }^{22}$ Ibid.

${ }^{23}$ Ibid. at para. 17.

${ }^{24}$ (2004) 98 A.J.I.L. 810.

${ }^{25}$ Ibid. at 814 . 
safeguards inspector, following a referral by the Romanian authorities, on a 2-year contract. In 1977 the Romanian authorities asked the IAEA to extend Rosescu's contract for 5 years, but the Agency renewed the appointment for only 2 years. In June 1978, however, it was the IAEA that asked the Romanian authorities in writing whether they would agree to a 5-year extension. This request was refused and the IAEA extended the appointment for only 8 months. Rosescu appealed directly to the tribunal with the agreement of the Agency.

The Tribunal ruled that the decision by the Director-General of the IAEA not to extend a fixed-term appointment of a safeguards inspector of Romanian nationality was reached through "misuse of authority" because he let "the interests of a member State [Romania, which opposed the extension of the appointment] prevail over the Agency's. The Tribunal found that the letter seeking instructions from the Romanian authorities and the DirectorGeneral's compliance with the direction of the Romanian authorities represented an abuse of his authority. Although it was understandable for the Director-General to consult a State member before appointing one of its senior civil servants, Rosescu claimed, it was improper for the organization to consult after the appointment, since by then he had become an international official with independent status. Once again, rather than reinstatement, the Tribunal awarded the affected staff person with damages.

In commenting on the case, Theodor Meron identified the mischief at work in this case as the absence of any security of tenure among U.N. civil servants from Eastern Bloc countries. He observed:

It is not necessary to discuss here the pros and cons of permanent appointments vis-a-vis fixed-term appointments. Suffice it to suggest that persons dependent on their governments' consent for reappointment and who have no prospects of permanent appointment often lack the moral courage to be truly independent international civil servants able to resist pressures from their governments. ${ }^{26}$

Cases such as Rosescu establish that independence within the international civil service depends on cutting the ties between those civil servants and their national state governments.

\section{The U.N. Office of Administration of Justice}

The UN's recognition of the need to entrench the application of a rule of law approach in the treatment of its own civil servants was recently evidenced by the General Assembly's resolution to establish the Office of Administration of Justice (OAJ).

\footnotetext{
${ }^{26}$ Theodor Meron, "Note and Comment: In Re Rosescu and the Independence of the International Civil Service" (1981) 75 A.J.I.L. 910 at 923.
} 
In the World Summit of 2005, the member states of the U.N. committed to a broad strengthening of the UN's oversight capacity, including the Office of Internal Oversight Services, expanding oversight services to additional agencies, calling for developing an independent oversight advisory committee, and further developing a new ethics office. ${ }^{27}$ This initiative set in motion both the opening of various ethics offices to address disputes involving international civil servants, and a restructuring of the U.N.'s dispute resolution and justice system, leading to the creation of the OAJ in $2009 .^{28}$ The OAJ's mandate includes providing a forum for addressing disciplinary measures that are taken against U.N. employees.

When an administrative decision is made that concerns the imposition of a disciplinary measure, or if it is a decision taken by the administration based on the advice of an expert or advisory board, the decision can be appealed directly to the newly established U.N. Dispute Tribunal. Article 2 of its governing statute outlines the purpose and scope of competence and jurisdiction of the Dispute Tribunal. Its substantive jurisdiction includes:

1. The Dispute Tribunal shall be competent to hear and pass judgement on an application filed by an individual, as provided for in article 3, paragraph 1, of the present statute, against the Secretary-General as the Chief Administrative Officer of the United Nations:

(a) To appeal an administrative decision that is alleged to be in non-compliance with the terms of appointment or the contract of employment. The terms "contract" and "terms of appointment" include all pertinent regulations and rules and all relevant administrative issuances in force at the time of alleged non-compliance;

(b) To appeal an administrative decision imposing a disciplinary measure;

(c) To enforce the implementation of an agreement reached through mediation pursuant to article 8 , paragraph 2 , of the present statute.

In these matters the Dispute Tribunal has the power to make binding judgments once it has examined the facts of a case and conducted an oral hearing as necessary.

Decisions of the Dispute Tribunal can be appealed to the aptly named UN Appeals Tribunal. Article 2 of the Appeals Tribunal's governing statute sets out the general scope of its jurisdiction:

1. The Appeals Tribunal shall be competent to hear and pass judgement on an appeal filed against a judgement rendered by the United Nations Dispute Tribunal in which it is asserted that the Dispute Tribunal has:

(a) Exceeded its jurisdiction or competence;

(b) Failed to exercise jurisdiction vested in it;

(c) Erred on a question of law;

\footnotetext{
${ }^{27}$ See "Implementations of Decisions from 2005 World Summit Outcome for Action by the Secretary General" p.2 at http://daccess-ddsny.un.org/doc/UNDOC/GEN/N05/545/06/PDF/N0554506.pdf?OpenElement

${ }^{28} \mathrm{~A} / \mathrm{RES} / 62 / 228 ; \mathrm{A} / \mathrm{RES} / 63 / 253$ 
(d) Committed an error in procedure, such as to affect the decision of the case; or

(e) Erred on a question of fact, resulting in a manifestly unreasonable decision.

The very fact of the review mechanisms set out by the Dispute and Appeals Tribunals speaks to the entrenchment of the rule of law within the U.N. as it confirms the Organization's recognition of the necessity of permanent forum with clear procedures for examining administrative decisions that may compromise the independence and integrity of its civil service. This is further evidenced by the Secretary General's Bulletin about the OAJ, which states:

The Office of Administration of Justice is an independent office responsible for the overall coordination of the formal system of administration of justice, and for contributing to its functioning in a fair, transparent and efficient manner. ${ }^{29}$

The manner in which the OAJ, through the Dispute and Appeals Tribunals, helps to achieve fairness, transparency and efficiency in attaining the independence of the relationship between an international civil servant and the U.N. as her employer can be observed though the Tribunals' jurisprudence.

In Hepworth v. Secretary-General of the United Nations ${ }^{30}$, the Applicant, Hepworth, contested the decision of the Executive Director of the United Nations Environment programme to not renew his fixed term employment as Executive Secretary of the Secretariat of the Convention of Migratory Species of Wild Animals ("CMS"). Included in the Applicant's grounds for complain was an allegation that decision to not renew his employment as Executive Director for the CMS was motivated by political considerations, and, more specifically, pressure and influence from the German Government to remove the Applicant from this post. The primary basis for the Applicant's allegation were two letters from the German Ministry for the Environment, Nature Conservations and Nuclear Safety to the CMS. The first letter was to the Applicant himself, asking that he turn his attention immediately to rectifying certain concerns that the German Ministry had with operations at the CMS. The Second letter was addressed to the Executive Director of the CMS. In this letter the German Ministry expressed concern about the Applicant's failure to address the previously outlined concerns; the letter noted that rather than addressing the concerns, the Applicant instead hardened his position.

The Dispute Tribunal's consideration of the allegation occurred within an analysis of whether or not the non-renewal decision was "based on improper motives or otherwise constituted an abuse of discretion." The Dispute Tribunal ultimately found against the Applicant on this point. In its decision it noted that the Applicant's allegation was primarily on letters from the German Ministry that expressed concern about the operations and management of the CMS Secretariat but did so not in a manner that would "allow the Tribunal to conclude that the decision not to renew the applicant's appointment was due to political pressure."

${ }^{29} \mathrm{ST} / \mathrm{SGB} / 2010 / 3$

${ }^{30}$ Case No. UNDT/GVA/2009/95 
While this decision did not fall in the applicant's favour, it does confirm that one function of the Dispute Tribunal is to ensure the political neutrality of administrative decisions affecting the employment of U.N. employees. That is, while in this case the Dispute Tribunal did not find that the decision not to renew the applicant's appointment was influenced by undue political considerations, it is the fact that it considered the argument as a legitimate argument worthy of consideration that suggests the Dispute Tribunal is a mechanism for preserving the rule of law within the U.N.

Gabaldon v. Secretary-General of the United Nations, while not a case about politically motivated administrative decisions, is relevant insofar as the decision in the case confirms the existence of a unique relationship between a the U.N. and its civil servants. In this case, Gabaldon, the applicant, was offered a six-month appointment as a Humanitarian Affairs Officer. The offer was conditional on Gabaldon being cleared by a U.N. Medical Doctor, and it was to elapse automatically if he did not receive the required medical clearance. After he received the medical clearance, the applicant fell ill. Prior to being able to commence his new appointment, he was required to re-sit for a medical exam; he was declared not fit, and his offer of appointment was subsequently withdrawn. When Gabaldon requested administrative review of the decision he was advised by the Administrative Law Unit of the Office of Human Resources Management at the U.N. Secretariat that he was not actually a staff member and the internal justice system was therefore not available to him.

Gabaldon appealed this decision. This appeal required the Dispute Tribunal to address the preliminary question of whether or not the applicant held a contract of employment with the U.N. The Dispute Tribunal ultimately held that the record did not indicate the applicant received a letter of employment or that such a letter was ever signed by an authorised official. Accordingly, the Dispute Tribunal held that Gabaldon was never actually a staff member of the U.N. who could avail himself of its internal justice system. This decision was subsequently reversed by the Appeals Tribunal, which held that "the UNDT Judge committed an error of law in denying Mr. Gabaldon access to the Tribunal solely on the grounds that the Appellant had never received a letter of appointment signed by an authorized official. ${ }^{31}$

It is important to note that the Appeals Tribunal did not itself make a substantive determination on the obligations owed to Gabaldon, only that that the Dispute Tribunal had erred in concluding that the absence of a signed letter of employment was itself sufficient to deny the existence of any such obligations. In this vein the Appeals Tribunal stated that it was for the Dispute Tribunal to determine if "following a thorough examination of the facts of the case, Mr. Gabaldon had satisfied all the conditions of the offer of employment and was entitled to contract-based rights with a view to his employment as a staff member within the Organization." 32

${ }^{31} 2011-U N A T-120$, at para 31.
${ }^{32}$ Ibid. 
While, at a high level, this case appears merely to be matter of employment and administrative law and practice within the U.N., what is notable within the context of this paper is the line of jurisprudence that was relied on by the Dispute Tribunal in its consideration of the merits. The Dispute Tribunal referred to the cases of El-Khatib $v$. Secretary-General of the United Nations and James v. Secretary-General of the United Nations, which both characterised the employment relationship between a U.N. employee and the U.N. as more than a contract between private parties. Accordingly, the reason for the Dispute Tribunal rejection of Gabaldon's appeal was rooted in the "special relationship between the United Nations and its civil servants." The characterization of this relationship as special implies that particular rights and responsibilities arise from the relationship between the U.N. and its civil servants, and that those rights and responsibilities delineate the boundaries of the rules that the internal justice system has been mandated by the General Assembly to interpret and apply. Although the Appeals Tribunal rejected the Dispute Tribunal's narrow interpretation of the El-Khatib and James cases, notably, it did not reject the cases themselves. Instead, it appears that the Appeals Tribunal expanded the scope of their application by holding that if good faith offer and acceptance of a job within the Organization has occurred, the lack of a letter of appointment does not obviate an otherwise binding contract and the obligations that it entails. Accordingly, the Appeals Tribunal stated:

a contract concluded following the issuance of an offer of employment whose conditions have been fulfilled and which has been accepted unconditionally, while not constituting a valid employment contract before the issuance of a letter of appointment under the internal laws of the United Nations, does create obligations for the Organization and rights for the other party, if acting in good faith. Having undertaken, even still imperfectly, to conclude a contract for the recruitment of a person as a staff member, the Organization should be regarded as intending for this person to benefit from the protection of the laws of the United Nations and, thus, from its system of administration of justice and, for this purpose only, the person in question should be regarded as a staff member.

Although the Dispute Tribunal and the Appeals Tribunal differed as regards what is required for an individual to constitute "staff", what is most important within the context of this paper is that there was no dispute that an individual who falls within that definition (whatever it is determined to mean) must be able to avail himself of the Organization's internal justice system. In fact, the Appeals Tribunal's decision that the internal justice system extends to use by an individual whose substantive, if not formal, relationship with the Organization is one of employee/employer further confirms the importance of ensuring that the U.N.'s obligations to its civil servants accord with the rule of a set of laws that have developed for the specific context of its operation as an institution.

The combination of the early case law out of the Dispute and Appeals Tribunals, the body of jurisprudence emanating from the ILO Tribunal, and the foundations in other legislative and executive instruments at the U.N., suggests that there is a non-partisan international civil service that both owes and is owed loyalty vis-a-vis the U.N. This mutual obligation of loyalty evidences the embodiment of the U.N. as guardian to a set of 
constitutive principles including the rule of law. If such a broader obligation exists, it must mean that contexts exist where an international civil servant's obligation to the rule of law (or other principles) will take precedence over competing obligations. Working out the scope of such an obligation, and the circumstances under which it may justify an international civil servant's conduct which otherwise would be in contravention of a specific order or direction, likely will fall to the Dispute Tribunal. In our view, it is possible achieve both independence and accountability in the oversight of the international civil service.

\section{Part Three: Issues for Future Consideration Surrounding the Relationship between the International Rule of Law and the International Civil Service}

The relationship between the independence and professionalism of the international civil service has never been more closely observed. As in many domestic settings, the reputation of international civil servants has become closely scrutinized and criticized. As Alvarez has observed, "Trust in international civil servants has been ... undermined by contemporary revelations (e.g., from the UN oil-for-food scandal to widely publicized rapes attributed to UN peacekeepers)."33

Corruption, venality and abuse of power remain important threats to the professionalism of international civil servants. The potential for external, national political considerations to affect the composition of - and, therefore, the operations and policies pursued bybodies within the U.N. is no less concerning, as the legitimacy and effectiveness of the decisions made by such organizations relies on their ability to make them independently. Given the political accord that animates the U.N. and other IOs, the first question we have considered is how to ensure accountability at the same time as guarding the independence of the international civil service.

Domestically, national constitutions provide for mechanisms of accountability. For example, in Parliamentary democracies such as Canada, ministerial responsibility ensures political oversight over public administration. The General Assembly has no equivalent of Cabinet in this sense. Thus, alternative mechanisms of accountability for the actions of international civil servants remain an issue both for the U.N. and for its member states to address. In our view, transparency itself may be seen as a meaningful form of

${ }^{33}$ Jose E. Alvarez, "Centennial Essay: In Honor of the 100th Anniversary of the AJIL and the ASIL: International Organizations Then and Now" (2006) 100 A.J.I.L. 324 at 344. For details on these and other scandals involving international civil servants, see See Michael N. Barnett \& Martha Finnemore, The Politics, Power and Pathologies of International Organizations, 53 INT'L ORG. 699 (1999). 
accountability. Therefore, requiring justification of employment-related decisions by U.N. officials, subject to review by independent oversight bodies such as the Dispute Tribunal, may provide a framework of accountability.

The second question we have considered relates to the need to safeguard the independence of the U.N. civil service from political interference. This non-partisan sphere cannot be guaranteed by legal and ethical precepts alone. If it is to be sustained, all participants and stakeholders in the U.N. must understand and appreciate the critical importance of its bodies (and those responsible for their operations) being able to make decisions free from the improper imposition of external political pressure. Again, in many domestic systems, this task of promoting and overseeing the professional ethics of the public service falls to non-partisan public bodies, such as Canada's Public Service Commission. ${ }^{34}$ Certainly, the ILO Tribunal and now the OAJ play an important role in safeguarding the international civil service's independence by way of dispute resolution, and in articulating the administrative boundaries that must contain decision making within the U.N. However, the meaning, and perhaps even effect, of these formal activities risk being undermined if the Ethics Office that is charged with, inter alia, ongoing monitoring, training and oversight is not active and engaged in fulfilling these duties. $^{35}$

The third and final question we have addressed relates to uncertainty about the duty of international civil servants to the international rule of law. Uncertainty about the nature and scope of the rule of law inexorably leads to the problem of whose definition of this concept ought to guide the international civil service. Does the rule of law require that international civil servants follow duly enacted directives from the General Assembly, Or, should they refuse to follow and implement General Assembly directives that contradict core rule of law values such as fairness and equality? Are the individual laws that collectively rule to be determined by international judicial tribunals, or is this determination open to subjective interpretation by the individual civil servants who are charged with implementing them? Must a civil servant be guided by how her supervisor approaches the rule of law? Is it up to international tribunals or national courts to delineate the scope of the rule of law?

These questions go to the heart both of the independence of the international civil service and will define the possibility of any notion of the international rule of law becoming a reality. The ethical implications of the international rule of law for the U.N. civil service (or any global and/or multilateral public service) remain a work in progress. The advent of the OAJ and the Dispute and Appeals Tribunals suggest an improved infrastructure at the U.N. to explore the questions set out above. In so doing, the Tribunal will need to determine the cultural reference points for civil service obligations. While liberal democracies such as Canada provide only one example, we believe the experience of countries such as Canada suggests that without an independent and accountable public service, the international rule of law will be a hollow slogan rather than a concrete reality.

\footnotetext{
${ }^{34}$ See http://www.psc-cfp.gc.ca/index-eng.htm.

${ }^{35} \mathrm{ST} / \mathrm{SGB} / 2005 / 22 ; \mathrm{A} / \mathrm{Res} / 60 / 248$.
} 